International Journal of Social Science And Human Research

ISSN(print): 2644-0679, ISSN(online): 2644-0695

Volume 04 Issue 12 December 2021

DOI: $10.47191 / \mathrm{ijsshr} / \mathrm{v} 4-\mathrm{i} 12-60$, Impact factor-5.586

Page No: 3899-3902

\title{
The Epic "Alpomish" By Fozil Yuldash Oglu and the Works of Hamid Olimjon
}

\author{
Shomirza Turdimov \\ Associate Professor, PhD. Institute of Language, Literature and Folklore of the Academy of Sciences of the Republic of \\ Uzbekistan Tashkent, Uzbekistan
}

ABSTRACT: This article is about the influence and inspiration of the epic "Alpomish" sung by Fozil Yuldash oglu on the work of the poet Hamid Olimjon, and the poet's article in the epic "Alpomish" entitled "In the place of the preface" and the poem “Kuychi's imagination".

KEY WORDS: Alpomish, legend, epic, tree, composition, poem, tumor, folklorist, research.

\section{INTRODUCTION}

The influence and inspiration of folklore, in particular, the epic "Alpomish" on the work of Hamid Olimjon is proved by the poet's article and poem, written in the epic "Alpomish" under the title "In the place of the preface" [Hamid Olimjon, 1999: 89-98]. Written for the first edition of the epic "In the place of the preface", this introductory article is intended as a specific indicator, a guide. But it has gone beyond the scope of the preface and has become a true scientific article.

The preface - the composition of the article is exceptionally impeccably structured. The author considers that the epic is interrupted from the process of live performance and takes on a new status - within the form of a book, which is presented to the reader for the first time. First of all, the history of the epic says that its roots go back to antiquity. The place of the epic in the life of the people, in which the historical truth is generalized and turned into a product of imaginative thinking, and this process continues continuously over a period of time, is noted in comparison with the genre of legend.

\section{THE MAIN RESULTS AND FINDINGS}

Illustrating the scale of the epic in "Alpomish", Hamid Olimjan cites the second of the two genealogical works, "Alpomish", as he emerges from prison, approaches his homeland, meets caravans, and inquires for the owner of the land. On the surface, this fact may seem inconsequential, but the astute reader realizes that the author has thought profoundly and ceased at this very tree. Since, unlike the previous tree of the epic, "Alpomish" was one of the biys of the past in Kungrad, and as the poet said, "... as long as the most prominent biys of Kungrad are counted, a very long time will pass before our eyes" [Hamid Olimjon, 1999: 84]. Every fact mentioned in the article shows that the poet studied the text of the epic, the art of epics, and the history of the people, observed and then began to write the preface, taking a very responsible approach to the views expressed.

According to the composition of the article, the definition of space came after the imagination of time, and Hamid Olimjon described it in the following way: based on

Boshida bor edi zardan chig'asi,

Yoz bo'lsa yaylovi Amu yoqasi...

(In the beginning there was a shell with gold,

In summer, the meadow is on the banks of the Amudarya...)

verses, he proves that the epic was created on the banks of the Amudarya. Folklorist Hodi Zarifov, in his research, also spoke about the region where the epic appeared and the origin of the bell seed: "ko"n" - sheep, "g'ir" - sky, chopagon - horse, fastrunnig, the third word means horse: Some historical data also confirm that "Ko"n" was once the name of a kinsmen. For example, in the work "Jome ul hikoyat va lome ul rivayat" the word "ko " $n$ " is given and it is written that "Khorezmshahs were from this tribe". This allows us to assume that the Mongols lived in certain parts of the Amu Darya, around the Aral Sea, and in certain parts of the Dashti Kipchak, that is, in what we thought was the homeland of the Alpomish, before the Mongols came to Central Asia. According to the Alpomish epic, Alpomish himself was one of the Kungrad. In fact, among the Uzbek Kungrad kinsmen there are also the kinsmen of kanjigali. This tribe includes "oq ko “yli” (white sheep), "kora ko “yli” (black sheep) and other tribes [Hodi Zarif, 1999: 85]. The scientist proves the hypothesis of the poet in a whisper. 


\section{The Epic "Alpomish" By Fozil Yuldash Oglu and the Works of Hamid Olimjon}

Hamid Olimjon took the reality of the epic as an entire, made a scientific and hypothetical observation, and attempted to get a full picture of the work as much as conceivable. The poet's intuition and power of observation permitted him to express the issues in a certain sequence, in the natural order, on a profound scientific basis.

Hamid Olimjon was first of all a poet. Figurativeness prevails in the poet's scientific way of thinking. This is natural. Hamid Olimjon expressed his scientific views in extraordinary metaphors and comparisons. He illustrated his popular scientific fashion. He thus introduces the bakhshi to the students, the place of this epic in the bakhshi repertoire; "Alpomish was his cradle of poetry" [Hamid Olimjon, 1999]. A short, succinct cast description. Hamid Olimjon clearly describes the themes of the epic, listing them one by one. The theme of love, which is the eternal theme of all centuries and peoples, is the basis of the epic "Alpomish"... In the minds of the people, the ideal of beauty is inextricably linked with the ideal of courage, justice, the rule of truth. There is no doubt in the minds of the people that one day humanity will firmly win. To do this, you need to be brave and fight with enemies.

It takes courage to do justice. You have to fight to reach the goal. That is why the promotion of courage in Alpomish.

"Alpomish" is an epic of courage. "Alpomish is a saga about a man who cannot be killed by the death" [Ibid. 85-86]. This description expresses not only the essence that the poet understands from the epic, but also his pride, emblems and dreams, as well as his inner call. The poet states: “... the people created the brave Alpomish in their imagination so that they would not be burned by fire, not by swords, not by bullets" [Ibid. 86].

The poet dwells on such poetic arts as metaphor and allegory in the epic: "These metaphors and metaphors may have become complex, beautiful, and ingrained" [Ibid. 94], he writes.

The poet's assessment of the people's heroes in the example of Alpomish and Barchinoy, who collected the royal verses in the epic, applies to all the heroes of the epic and does not lose its value as long as folklore is stable. It retains its place as a Christian criterion for all epochs and generations.

Hamid Olimjon emphasizes the importance of folklore, including the epic "Alpomish" for modern literature. "Finally, Alpomish is of great importance to our writers as well" [Ibid. 95], the author first understands this importance in the following sense: "Alpomish" shows our writers how important it is to know folklore. The importance of folklore will be great for the development of Uzbek literature, for making its language a true folk language, for making it simple and deep, and, finally, for making Uzbek literature truly popular in general" [Ibid. Pp. 95-96]. These words of the poet are still relevant today and are an exemplary advice for all.

Hamid Olimjon had a special love for folklore, performers of epics, in particular, the epic "Alpomish" and the poet Fozil. We can clearly see this love in the poet's poems, epics and articles. In general, the connection with folklore in the poet's work cannot be measured in terms of folklore alone. As the saying goes, "Saying halva does not make you mouth-watering", the term does not fully capture the value of reality. We can clearly see the unity of Hamid Olimjon and folklore in the work and scientific heritage of the poet in the example of the poem "Kuychi's imagination" [Hamid Olimjon, 2019: 37-40]. There is a word in Uzbek called ola (or ala). This word has a special place in our mythology, rituals, customs, myths, folklore. A simple example: Our grandmothers used to hang white and black threads on their babies to protect them from disasters. Get the color of the glasses. Gorogly was also raised by Olabiya as a "mother". The count can go on and on. In a word, in contrast to the in-yan sign, term and concept, which is considered to belong to the Japanese, Korean and Chinese, which are known to the world today, we Turks have a simple OLA color which gives concept, sign, and meaning. Ola is a world of black and white, hot and cold, night and day, winter and summer, a man and a woman. There is also unity in the confrontation here. Hamid Olimjon's work and folklore are of this color.

The poem "Kuychi's imagination" is dedicated to the famous poet Fozil Yuldash. Numbering is divided into six parts. Each part has a certain inner meaning, and these meanings are intertwined and serve as a whole, a common idea and thought.

Parts 1,2,4,6 of the poem consist of 3 quartets, part 3 of 4 quartets, and part 5 of 5 quartets for a total of 21 quatrains. Probably a coincidence, but this number corresponds to the Alpomish epic: the alp's childhood -7 years, puberty -7 years, maturity - 7 years, a total symbolic 21 years.

Parts 1,3,5,6 of the poem: in the form of a, b, a, b; Part 2.4 is rhymed in the form a, a, b, a, and is written in a melody way that is widely used in 11-syllable epic and ceremonial songs. This melody path in Turkish poetry is considered the melody path of scral texts.

From the content of the first four verses of the poem we see that the life of the ethnos, the artistic expression of its destiny in the epic is a description expressed in the form of a cast poem:

Bu xayol so'ngsizdir, osmon kabi keng,

Bu xayol tugamas hech hali-beri.

Uning boyliklari umrlarga teng,

Hamon belgisizdir boshlangan eri.

U sira to'xtamas, toshar doimo, 


\section{The Epic "Alpomish" By Fozil Yuldash Oglu and the Works of Hamid Olimjon}

Qilib bo'larmikin uni hech bayon?

Cho'llarda darbadar, tog'larda tanho,

Har kecha yangi sir bo'ladi ayon...

So'zsiz hikoyalar, eng buyuk sirlar,

Birdan tilga kelar daryoday toshib,

Yuzlab qabilalar, o'nlab asrlar

Uning osmonidan o'tar adashib...

(This imagination is endless, as wide as the sky,

This fantasy is never ending.

His riches are equal to life,

It is still unknown where it started.

It never stops, it always falls,

Is it possible to explain it at all?

Wandering in the wilderness, alone in the mountains,

Every night there is a new mystery...

Wordless stories, the greatest mysteries,

Suddenly it flows like a river,

Hundreds of tribes, decades

Lost across its sky...)

The poem is understood as an appeal of the young poet to the old poet. The young poet immerses himself in the imagination of the old singer. He strives to understand it. Kuichi marvels at the vastness of her imagination like the boundless sky, its infinity, its richness, the uncertainty of her beginning husband, the inability to describe the boiling. It is amazing in the face of a huge MYSTERY. If we pay attention, we will understand how wide the meaning of the word fantasy is in the poet's manual.

The second, third and fourth songs tell the thoughts and observations directly related to the reality of "“".

"Oshiqning fahmidir qorong'u kecha",

Quyosh uyqusiga to'yib turguncha,

Ko'zi yoshliqlarning bordir yo 'ldoshi,

"Yig'lasam, holimga yig'lar bir necha..."

("The lover's understanding is a dark night",

Until the sun is full of sleep,

The companion of tears,

“When I cry, some people cry for me ...")

The poet takes verses from the epic songs and recites them in his own experiences, in the thoughts that reveal the idea of the epic.

Qirg'oqlarga urar daryo o'zini,

Osmon qurshamishdir tuproq yuzini.

Bahoriy dashtlarga, gul vodiylarga

Oy Barchin tikmishdir qora ko'zini...

"Ot chopsa gumbirlar tog'ning darasi,

Urushda bilinar mardning sarasi”,

Oltoychalik yo'lda qolgan sho'r elning

Ko'rinarmi yulduzining qorasi?

(The river that hits the shores,

Heaven surrounds the earth.

To the spring steppes, to the flower valleys

"Charming Barchin's eyes on the road...

Horses galloping in the gorge of the mountain",

The best of a man known in war,

The rest of the poor people on the road to Altai

Does the star look black?

In the fifth song, the young poet expresses his dreams and aspirations in the core of the old singer's thoughts and songs, the changes in the ethnos life of the epic; it is thought that it symbolizes the ups and downs, and which part of this epic of his time corresponds to it, concludes: 


\section{The Epic "Alpomish" By Fozil Yuldash Oglu and the Works of Hamid Olimjon}

Kuy ko'pdir, isyonkor dod kechasida -

Benomus etildi Kuychining qizi;

Kuy ko'pdir, Kuychining peshonasida

Jazo otryadining tovonin izi.

Dorlarga osildi juvonning eri,

Qo'shiqlar etildi majruh va betob,

Sahroni qoplagan elning shoiri

Qolib ketdi cho'lda bekitob.

(There is a lot of music, on a rebellious night -

The daughter of a singer who was dishonored;

There is a lot of music, on the singer's forehead

Trace of the punitive squad's compensation.

The woman's husband hanged himself,

Songs were disabled and sick,

The poet of the people who covered the desert

He was left alone in the desert.)

The last song in "Kuychi's imagination" ended in an optimistic tone. This optimism is not modern. Folklore is in harmony with the conclusion:

Kuy aytar bulutlar ichidan inson,

Kuy kerak mardona, juvon hayotga.

Kuy aytar lochinlar o'lkasi — osmon,

Ota, qo'shiq aytgan etar murodga!

(A man sings among the clouds,

One brave melody needs a life.

The sky sings that is land for falcons,

Father, whoever sings gets his wish!)

\section{CONCLUSION}

To conclude, Hamid Olimjon's poem "Kuychi's imagination" is one of the few poems in our literature that has been interpreted several times, on several levels, and repeatedly referred to by researchers. One of such layers is that the poet's work is "ola" color in harmony with folk melodies, image symbols, ideas and content.

\section{REFERENCES}

1) Hamid Olimjon. (1999) In place of the preface. "Alpomish" is an Uzbek folk heroic epic. - Tashkent. Fan. - pp. 89-98.

2) Hamid Olimjon. (1999) In place of the preface. "Alpomish" is an Uzbek folk heroic epic. - Tashkent. Fan. - p. 84.

3) Hodi Zarif. (1999) The main motives of the epic "Alpomish". "Alpomish" is an Uzbek folk heroic epic. - Tashkent. Fan. - p. 85.

4) Hamid Olimjon. (1999) In place of the preface. "Alpomish" is an Uzbek folk heroic epic. - Tashkent. Fan.

5) Ibid. pp. 85-86.

6) Ibid. p. 86.

7) Ibid. p. 94.

8) Ibid. p. 95.

9) Ibid. pp. 95-96.

10) Hamid Olimjon. (2019) Selected works. Tashkent. - pp. 37-40.

11) Alpomish - an Uzbek folk heroic epic. - Tashkent. Fan. 1999. - p. 179.

12) Hamid Olimjon. Selected works. Tashkent. 2019. - p. 321. 